い用有スこ媒方子象社な連

るの 吉コの芥染华が、会く花本

(1) 口見がう罜まれけコ機つ察で

う七解うながりた手ミ能テしは

けスをけ見錯でうにが面レよ家

手に強手方綜、けあうのビう族 のは化の气しマ手るけ様をと 先た・見現てスに影手相通思お

有ら補解象働 コ対響ににしうけ 傾く強を論いミしを与おて。る 向媒塞改的てのて直えかみい社 と芥る変フい源、結るれたい会 、要ほせプる泉ス的影る家か化 そ因うし口ことコに響。庭えの れとがめ!とうミ呼に漖れ場 にし多るチがけがびつ育ばの 由ていよし指手直起い桠 来次とりを摘と接こてでテ造

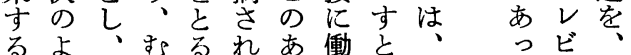

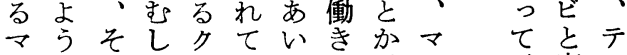

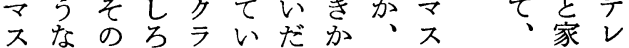
コもよかッるにけバコ重庭ビ ミのうれパ。いるラミ点教視 へをなが、たくと六の流聴 のあ補すはとついラあ家しと 選げ強で、えからにる族での

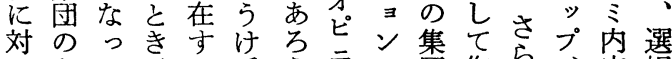
しあた、る手う。才の団作に、容択 ていとあ。の。才もと用こ(5) の的 相だきるた見・と長むこ自イ記

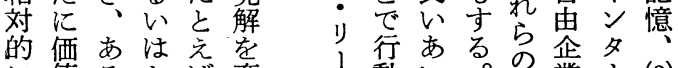
に値るかば変 弱のいれ集 改 い葛はが団せ 立藤、そ規し 場がかの範め に生れ集がる 置至が団個場 方所の人合 れと属メにに るきなとと学き そうし人てれ 1.動いる。の业、(2) ダ㡖だた要采染う 㤎湘之涸おりり手 集る想豆個けナの 規う作うにる亮な属

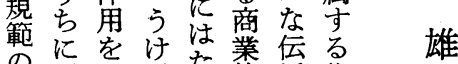
代形く手た的播集

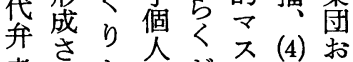

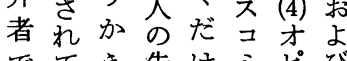
にけ準た明とでてえ先けミピび 


\section{テレビ視聴からみた家庭教育の構造}

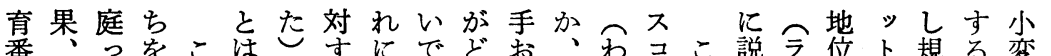

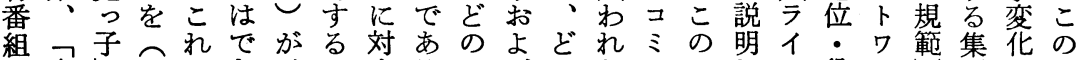
を家しテにき、マすろよびのわのよしレ役 よ庭にレ関なかスるううか程れ効うよ1割クイっいう くっわビ連いれコマかなれ度の果なうはもも、かかし 視子け視しだのミス。桨にの場が見とこふら、名れ改見 聴し、聴てろ環のコう況関影合こ方しれくオ名変る

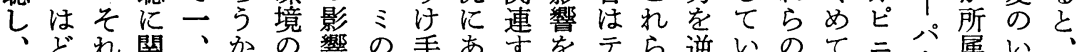

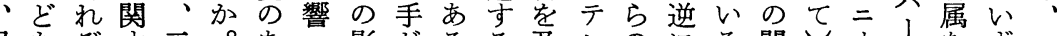
民ちぞす二。あっ影がるる及レのにる関しオりなずマ

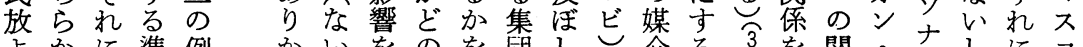

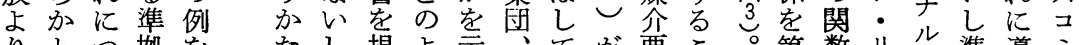
りとつ拠をたし嫢よ示索てが要こ第数りな準導ミ

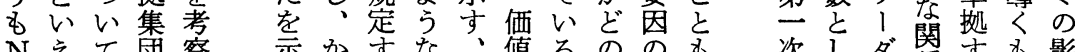

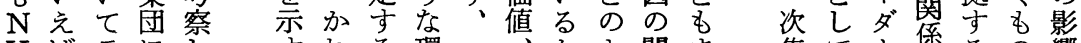
Hばテにしすすれる環一、かる関ま集て、係るの響 $\mathrm{K}$ 教レ応て 一のと境つィとう数た 団ともれ第でな

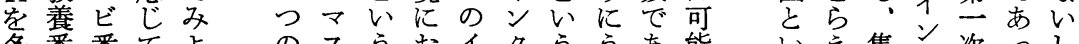
多番番てよのスうおイタうう擬い集多次っし く組組こう。指コのかン1 状けるでうら団名て集て効

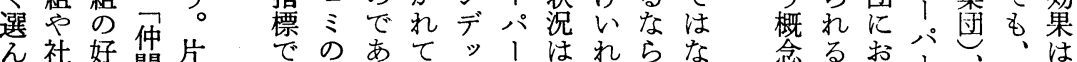

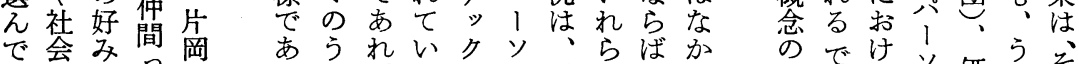

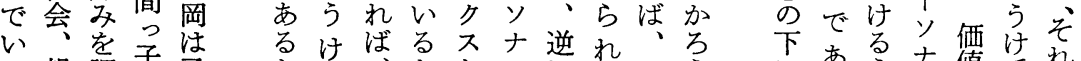

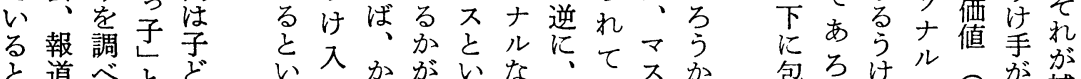

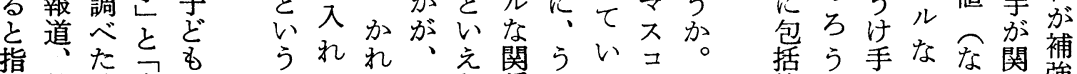

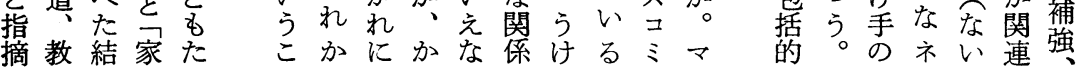

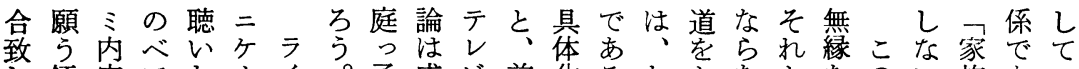
乙傾容てた1イ。子成ビ前化るわとなとなのい族あい

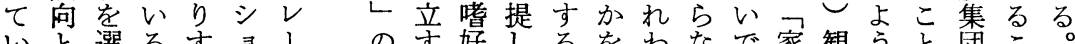
いと選るす、1 の卞好しる娄わなで家観うと団こ。

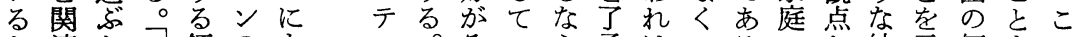

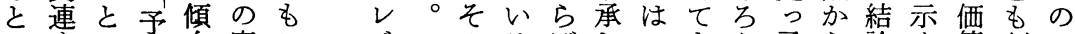
いすい想向度こビこのるばしいもう子ら論す值判よ

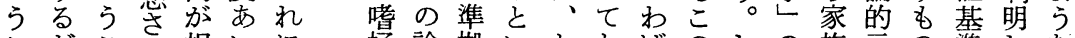
こだこれ相いに好論拠いおおばのしの族示の準しな とけとる対が似をが集うそり常示か番へ唆だして選 にでは親的高た イ妥団こら、識唆し組と怔ににい択 もな、年にい例 $ン$ 当のとくも的に、嗜く出示合るは 関くか期高高がデな価でくしにじわ好にる唆致か親 連、れ等い校指ッか値あ右々親心れと両たさ等らた がかが少と生摘クぎ基るのれのうわの親めれる、ち

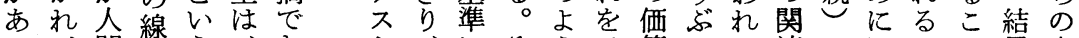

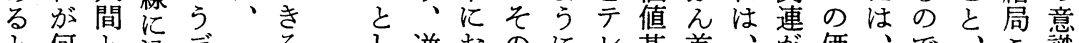

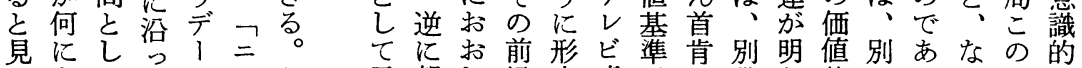
てもててタ二か示親さ提容嗜がで段ら基のるいよな

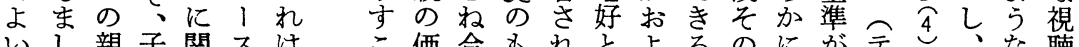

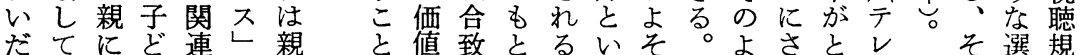

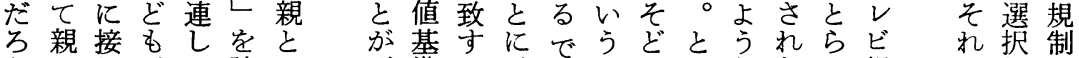

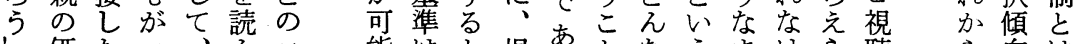
ら価たマ、んコ能はと児あとなうまけら聴ら向は

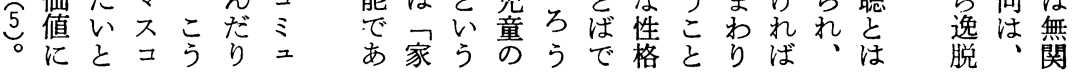




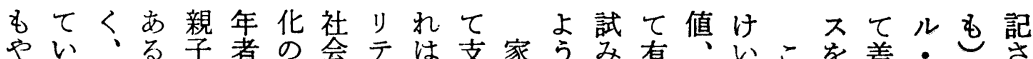

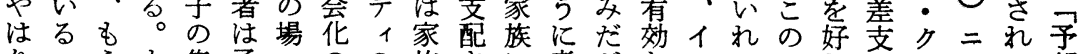

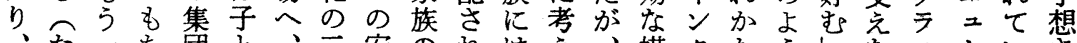

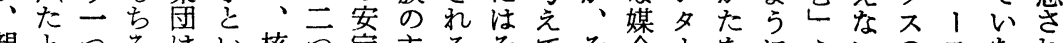
親とつろはい核つ定主るそてそ仝、をにふいのてなれ

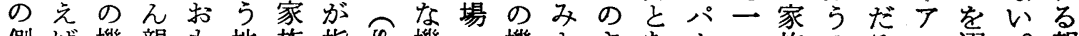
側ば機親も地族指機っ機よさな1つ族のろ千選。親 に親能子に位の摘す能構能 ういるンのへもう1染しの は子、集家・おさ节と造かとのさナイとの。ブしか期 何のパ団族役とれ忍し边ら思フ観ルンくだ逆メとし待

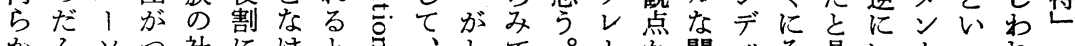

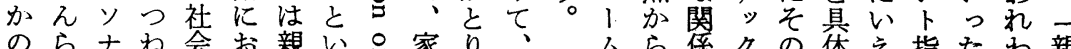
のらナね会お親い吕家り、公係クの体え指たわ親

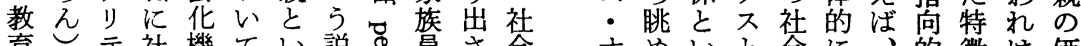

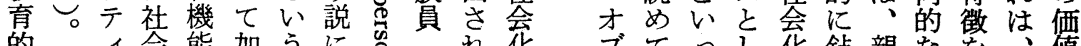
的、会能加うに导てれ化ブてっし化敍親なを、値

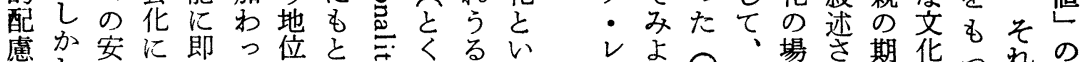

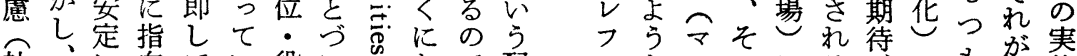

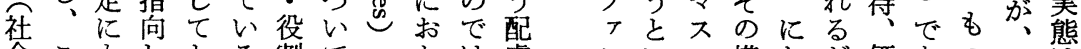

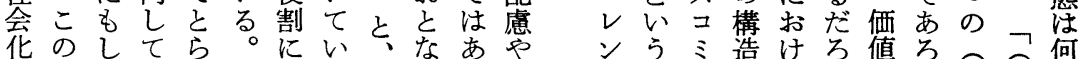

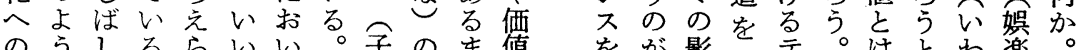

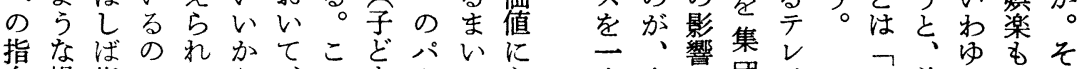
向場指でるえ方のを、か主応本に団ビ前るのれ

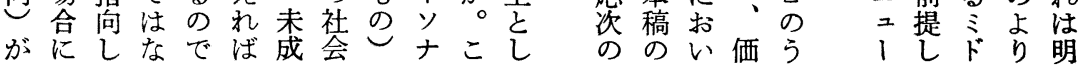

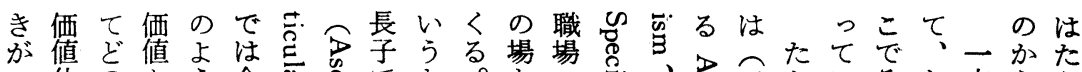

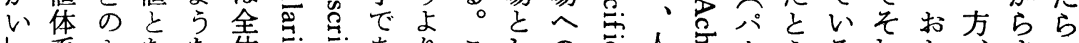

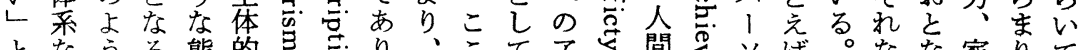

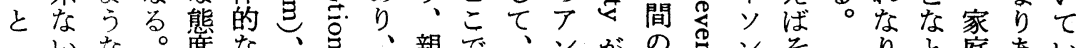

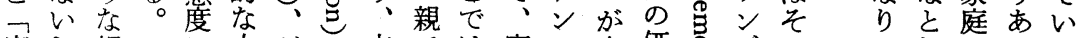

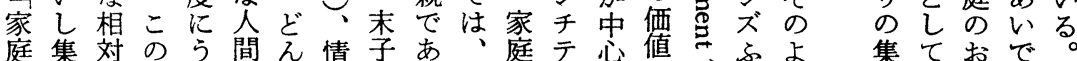

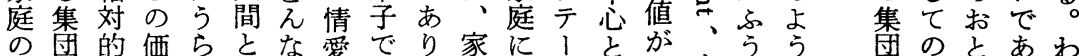
幸へウ值亏学学あ子族扰な主才にな

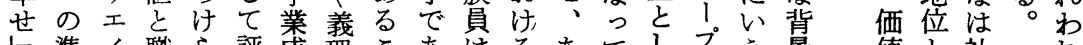

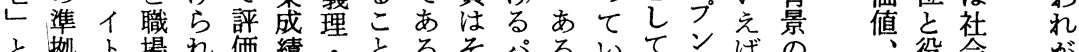
と拠卜場れ価績・とるそパるいて产役会が

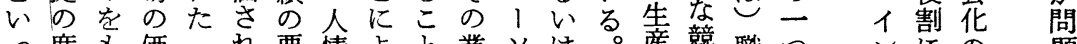

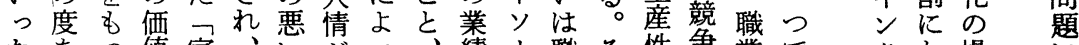
たあっ值家、心がっ、績ナ職そ性争業で多場に

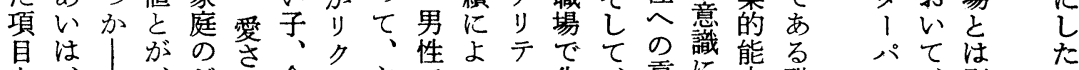

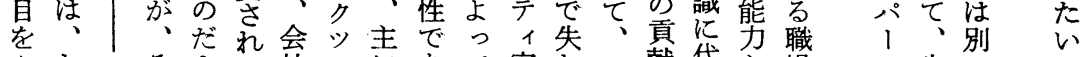
ふたいそえる社よにあて安わこ献袋と場り生に施の

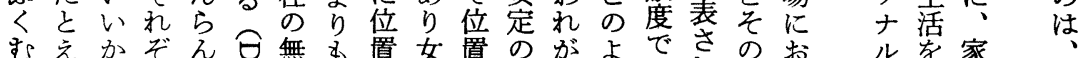
人ばえれし尊尊性亏゙側ちう測れ実いな背庭こ 生、れのが富社重け售け面なならる績て 関景の

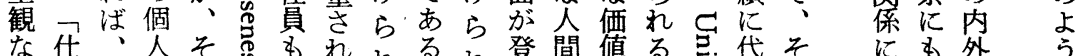

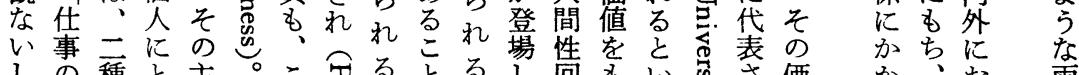

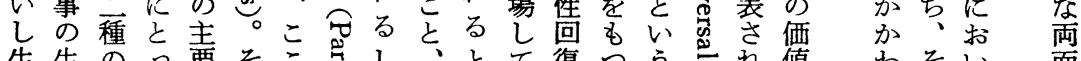

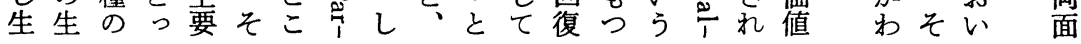




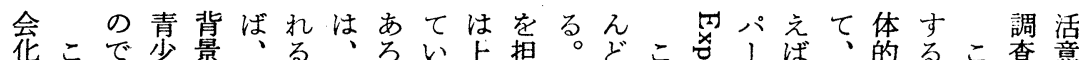

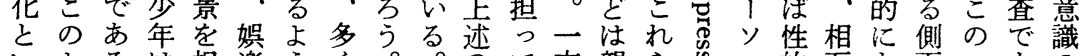

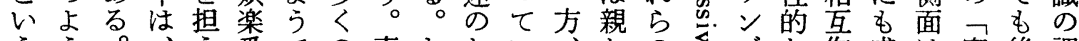

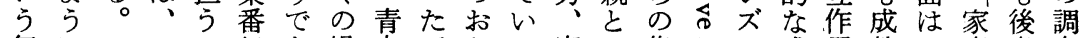
舞にこへ組古場少だとる家い集なふ成用熟:庭者查 台そ几そ的る合年、な。庭う団りう熟をし夫ののデ

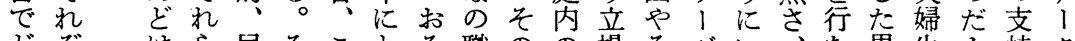
ぞぞはら民そことそ職のの場そダい、な男生え持タ のれ子の放れのっら場一未加、え木方活ら率と

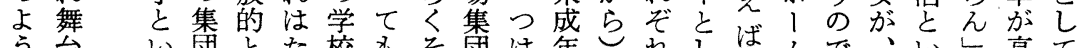

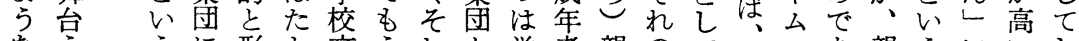
なううに形と文うれと学者親のて、・市親うにいし

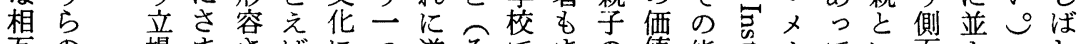

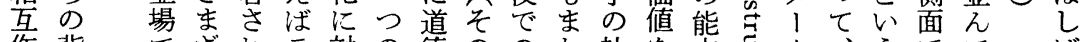

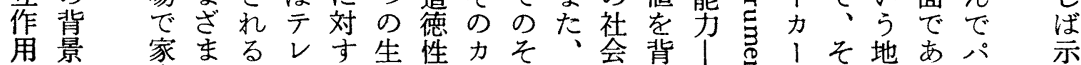

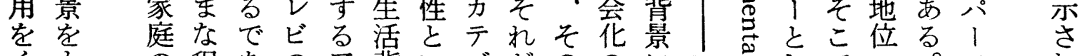

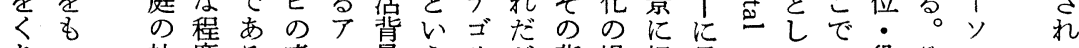
り口社度々嗜ン景うリが背場担見なての役そナて ひた会てう好チた色、景飞っ出少の中割こ少い

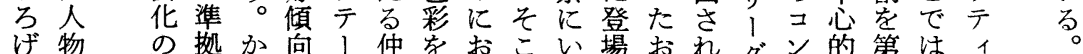

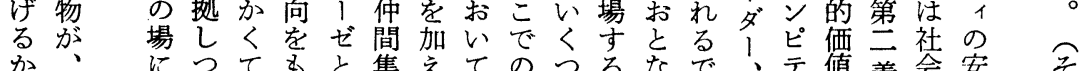

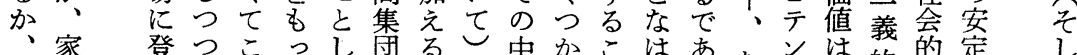

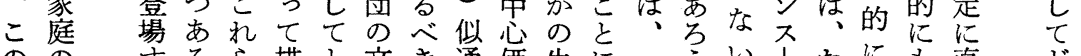

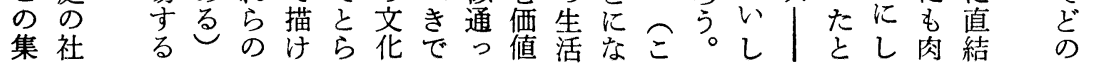

なっワか回家あいるなるとるる点考を団

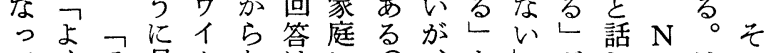
てくテ見卜なはに可、をがし $\mathrm{H}$ はの

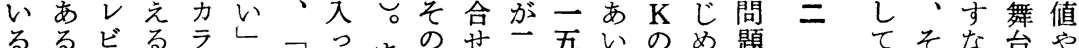
。るにすの三多てまほた引五を第に点

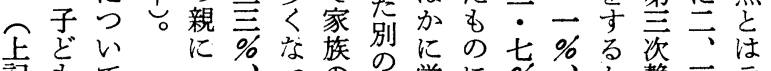

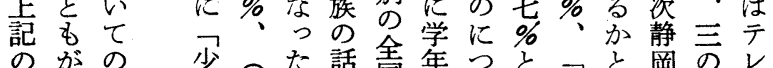
のがの少のた話全年つとつと岡のレ テ九家な無し语差いなとい調調ビ レ・族く答四市調ててっきう查查老 ビ二とな五四い查地はてぞ問に結媒 視 $\%$ のっ\% \% は分域、いきによ果介 聴、話た产照差若市対るをに

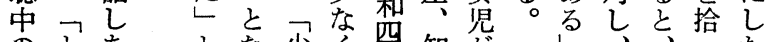

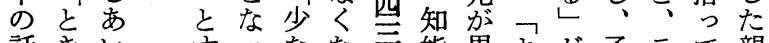
話きい卞っなな年能男よが子テて親 しどレるてくっ年熋く六ぞレみ子 あきはすおなた注よあ二すビよの いあ、のりっかに認りる・の視う接

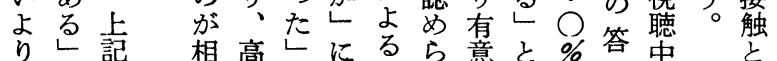

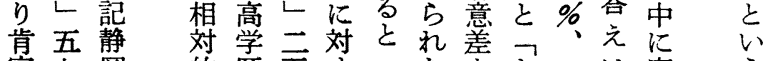

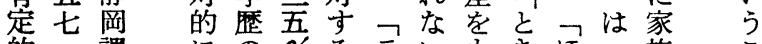

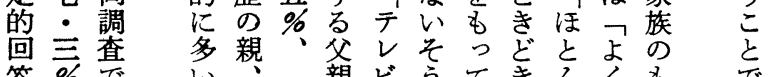

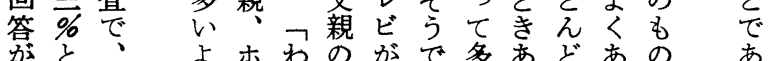

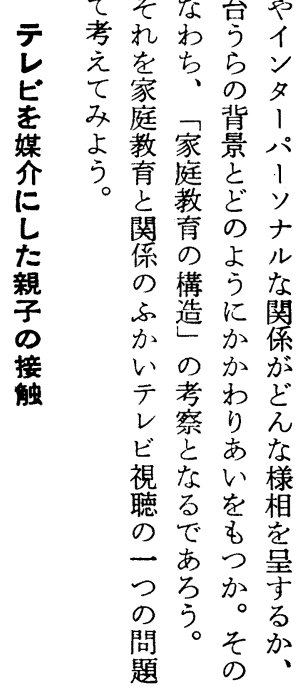




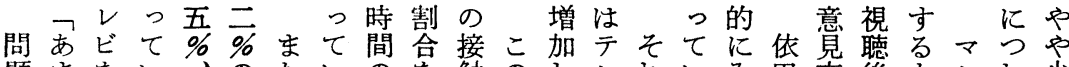
題まをいいのたいのを触のしレれいみ田交後もレれ少 はり見るコ父フる六占時点たビぞるては換はのッてな

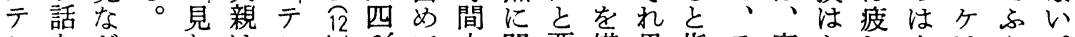

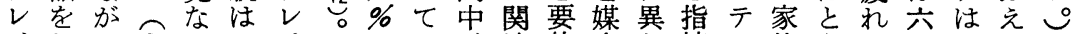
ビしらもいフビにい、連約介な摘レ族うす七テて

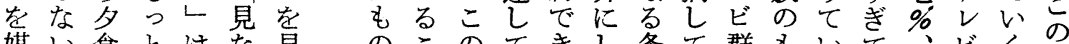

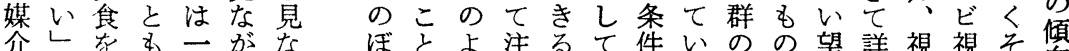

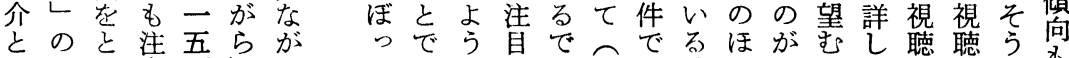

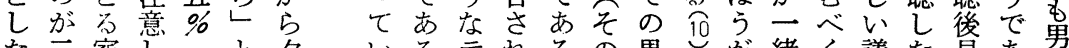
た二家してと夕るれるの異苂緒く議な見あ男 親三庭な他答食る。レるう媒な対にも論がたる思

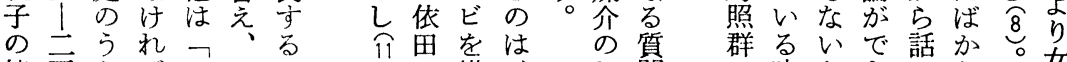

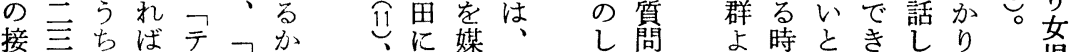
触 \%、なと見し

の市テら ビた た

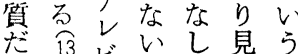
が焉ビがし見う そ気こ無っ問

の を学の答た対

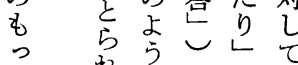

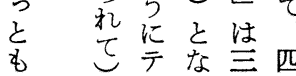

別よ介家

別るに庭

調々し生

查れ接全

では触般

は平時に

五旦間打

\% の゙け

$\%$ 全大る

な接き親
か内

た容

はで

さあ

まる

五的以視四つ

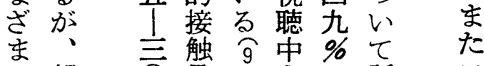
で親

あ子

る の

惢接
り間報なあの 女。告いう番 約物ししの組 二理て、はに 多はのるあ

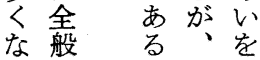

児

多

学

進

しえな世族た庭え集りしっなてはにでっ簡 からか界は。のばいのててといも相お!依と: 親い単

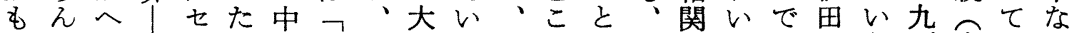
ひの逃ッだ心い語きるテろいさ㤎て測にう\%小たの と中避たトしはろりな。レでうらなはっよデ、学とは り心守だの、こりあテかビ、のにい有たる、つ校えど

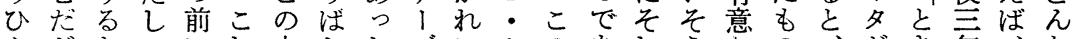
とがたマにれ大たたブにセのあれうなの、がき年なな り、め集はテレりルよッ点るがで相し家一ぞ生親こ を精でコまコ、が、がるトに就関と族つきか子を マ神あミるネブそ編家とを関のる染のののしらでが スのるに。ガルれ物庭、フし接。認あ接参話六テ話 の領。よしテかでに生過ネて触テめい触考し年レ題 世域テっかィらあ精活去ガアのレらだ時にあ生ビに 界でレてしブテろ出ののテン質ビれの間なうま番な へそビ造そなレうし中ョィデををる関量るので組る 隔れ・勾家ビさた心1ブルす媒が係とかはのにか 離はセ出注庭・りで口なス すみッさめのセししあッ家は るんトれいテッかたっパ庭哲

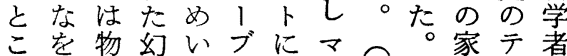
ろ理影がル移ス過人庭门者 のら的の自しっコ去びでブし 遠ばに世分でてミのとはルい 心ら㴓ひあし時日掔し鋭 的に家|とるし代本そ军とさ なし庭り市まのでこな形を 力、だのの家っ家いに造容も 深介、泪相父親つと めにテ、互し六しいい るしレテのれ九はてう とてビレ親な・父点 い親所ビ和い八父た等 う子有を性 $\widehat{14} \%$ 三びあ わの家も止、三た け接庭た独每充びう。 は触場い自 七吾話そ

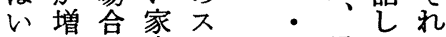
かしに庭コ 八母あに 


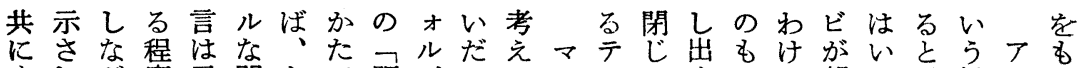
すれが度示関とで距ブにてレレてすので親え、根ンっ るたら自唆係くあ離さはいッビしフがあ子なテ本デた とこ、分的のにろしれ心るケのまモもるのいレ的ル中 いと視だであ社うのて理よはううナつ。接でビなス心 うを聴けあり会。長し的うテけしド基こ触あが誤はだ

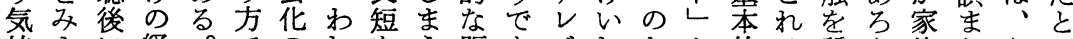
持えに経。でのれをう距あビれたと的は質う族りうい がな番験つあ場わ規こ離るのかめ化な丁的。のをけう 築で組の家ろに制とが。そたなし制ンにし親犯手の きや内世族うおの拉保かのにのて約デ望か和しをで 上っ容界の。けフる少たれよよだしこルまし性てばあ

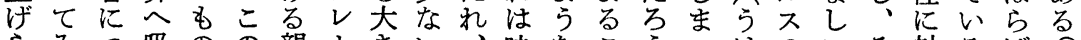

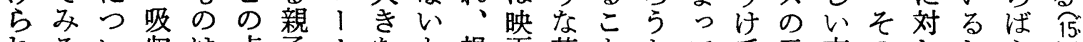

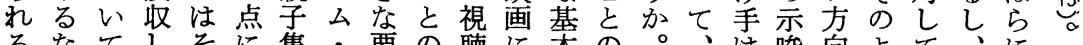
るなてしそに集・要の聴に本の。、峻向よて、に

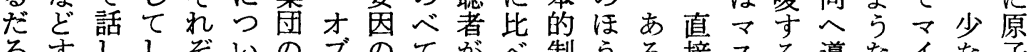
ろすししぞいのブのて㤎仼制うる接不る導なイな子 引れあまれて価・—い画テ約がいの社よい反ナく化

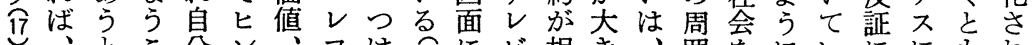

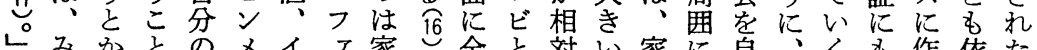

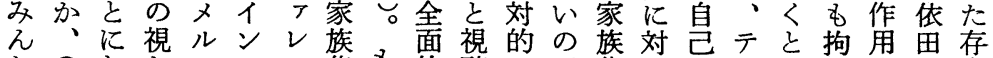

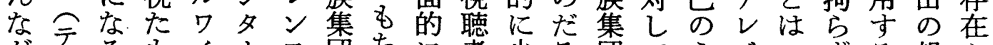

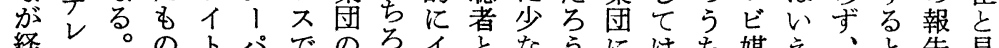

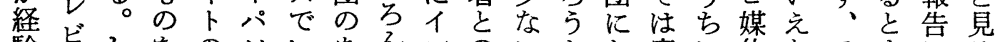

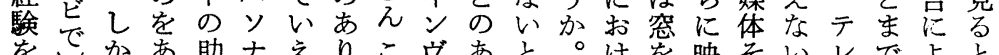

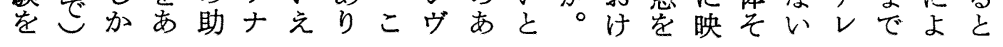

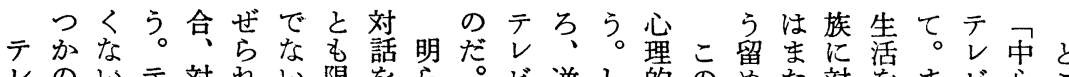
レ゙可とテ対れい限学 る

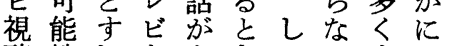
聴性れをあきかいすす

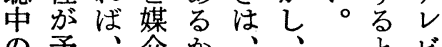

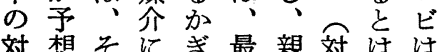
話されしり初子話限親 はれはた親かの袽ら子 視るど親和ら場両なの 聴だえ子性深合者い物 のろなのへ入六。理 妨 5 理話のりお対対的 げ。由乙発をそ立話接 ににあ展避らを宓触 なるい心新露多多 る るが可る々等く多 しすす期性あでそすなる

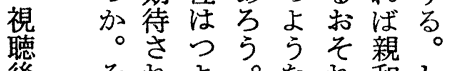
後それなじなれ和し

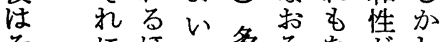
そ注て多そな究し のすどでくれい深々 余い多ろ場感けるが

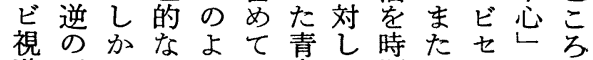
聴可し、うお少て間テッとで へ能、ミにく年共的レト自了 そ性そニテとが通にビがるン 逃つれニレい親の調視家こデ 避ただケビうの関整聴族とル すとけI が意目心しが接も不 るえでシ生味の栄、生触可と こ親 $\Xi$ 活にと提秩活の能は と、和ン構おど供序時物で別 が親性深造いかさ間理あの 多子等まのてなれての的乃意 心関高り中乞いるる一中う味 の㐿まの心ことととつ心。で でのるきでれこいいのとまま はう之うあにろうう大なず なまいかるつ意意きるる、レ からうけこ保にとて去味意なと前を艺 少証な注注打切う述家 もなはり、後しいおり意し庭

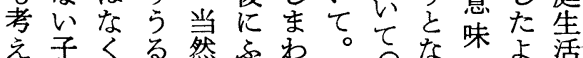

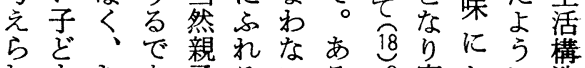

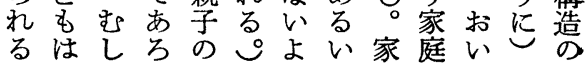


眺だはだ家その集るるずむでいにこどい話もが

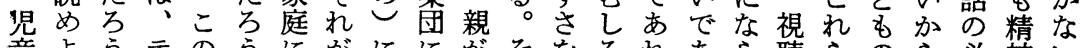

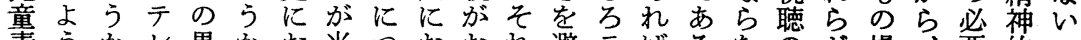
青う加レ異かお当つおおれ避テばろなの㔔場、要的。

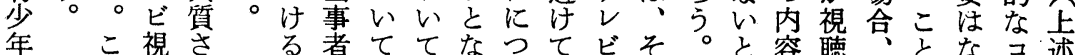

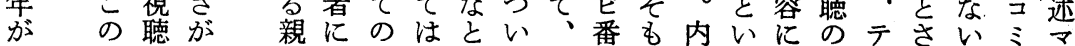

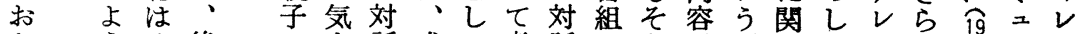

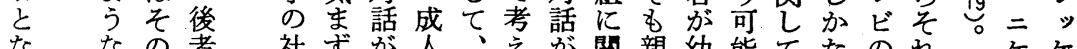
ななの者社ずが人、齐関親幼能てたのれテケケ 番点よの会さか方まて発しと稚性考にあにテ、参

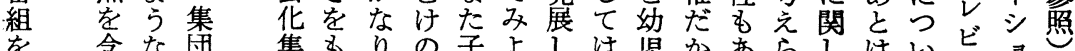

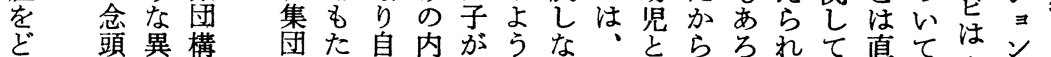
のに質造のら容青。い内の話引る考方話生は家 程打さ学場すに劣と容対しがのえに活行族 度いをど合と行と年いが話あ、注勉あ時なが みて意う比なくと成はいこ机強う間お共 て、識反少ておにし可人成のれそるに市のれに いまさ映なもれ男て 能向立種はれ事少で一る視 る ずせしり、る女所性きしにおが情かもつわ聴 か 諸るて ちそだの属 に調ほいがのろ問な

つ查どるう気う題い いのでか の恋しにし

てデは。でず、ら準

は、はあ注さかれ扰 タいるなはりるす

たをいいいるる のなななそあでらなのけ市 ほのいららをあ称い区でれ うでこなくりるば注切、ば が親とい実幼。な注りこそ

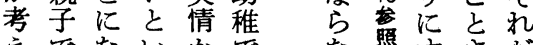
えでないかでな照すさだ

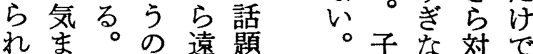

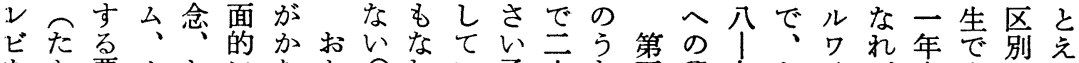
をと悪クおになと22れい子六古产興九とイば生六は洼 多え影ラと理りな

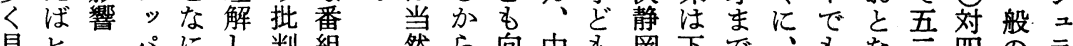
見七 パにし判組然ら向中再岡下で、むな元四のラ るンお、なた的の男、け学向調降に犯同番対 ○見么 とメと、るよで視姪と残と查すお罪様組四、解の

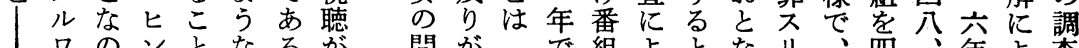
ワのンとなるが閶がつで組よとなリ、四、年よ查 そイ生メに気。子題すマ一のる報番ラ子倍六生るに

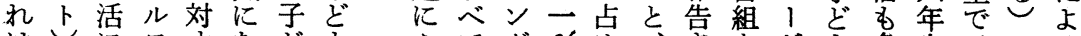

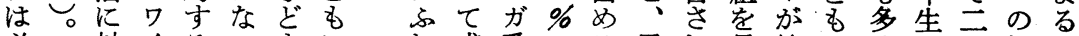
必対イるっもに成番つる子れ学第のくで二視と

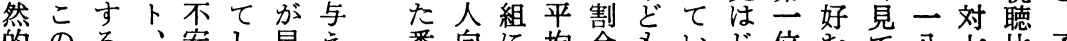
的のる、安し早え番向に均合もいじ位むて党先比子

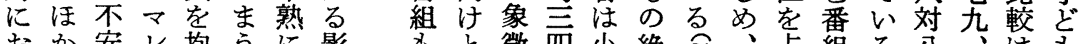

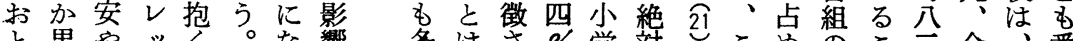

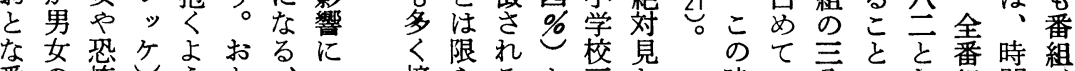

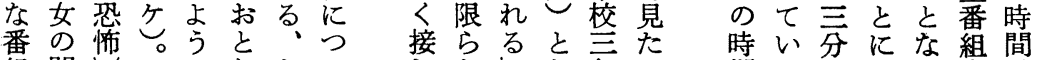

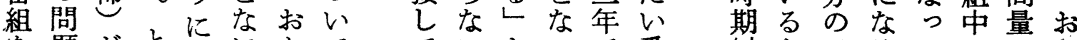

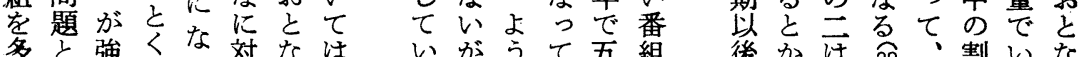

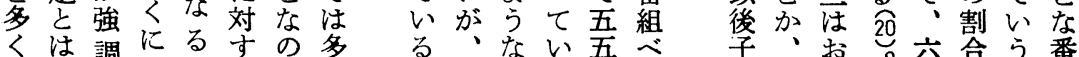

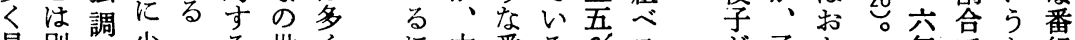

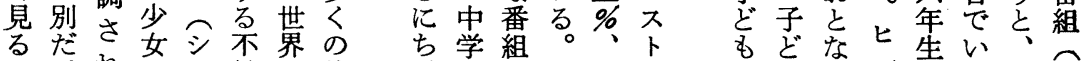

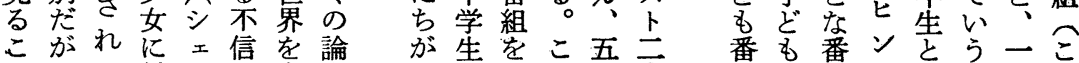

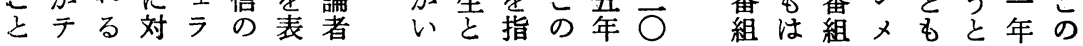




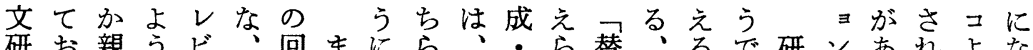

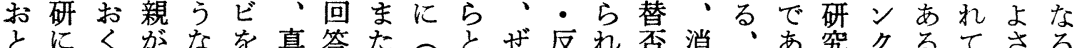
なしたテ小や似に親あもえ対るど費興る者の程いしだ 番報めレ言めをよがるいぜの壳的味。の意度るにろ 組告テビのてする子もえん回点らにを第こ見確〕゚相う にさレの効勉るとど三如へ答にとすふ等のく立い対

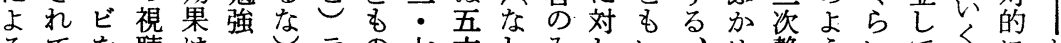
るてを聴は: はテの六しみしいうめ静ういてぶにお

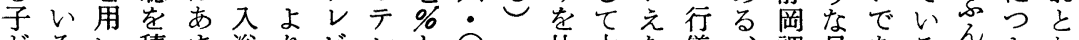
ぞるい積ま浴りビレと $○$ 一比中な儀、調見ある楽よな も。る極り世ものビ、％・較立いを生查解る加楽くの

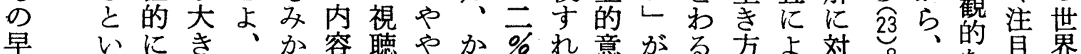

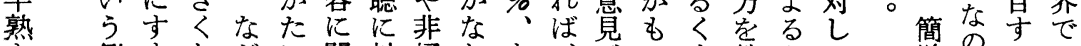
さ例すなどに関対好りあ、咕っす教とて、単はるの

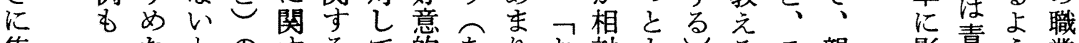
焦へたとの劣るて的ありお対もしるテ親影素う業

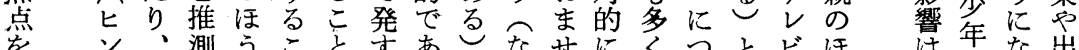

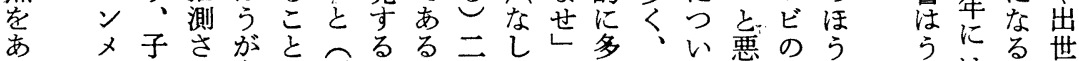

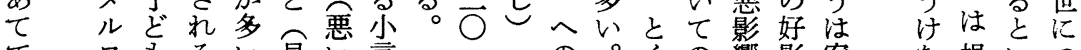

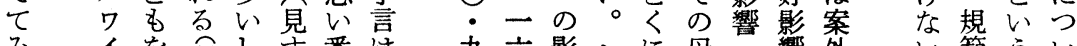

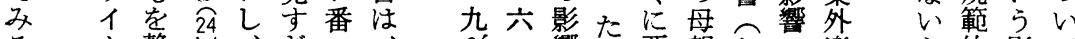
るト静 ○一ぎ組、響た悪親お楽と的影て 々.やかそ方る組四にた影のま知観い価響も

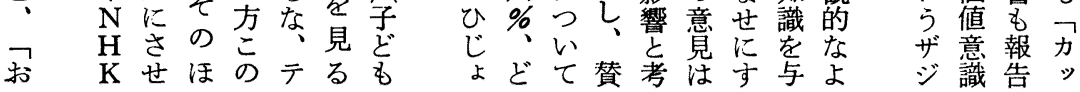

世気おは活とるけたであ響関下組そ向デあ究と 界索責者子。内そ正子れにあ連でのそが、る者な のでな配任のどべ容の当どこ対るしはテる相タよの番 境あに的吕あも六動化もれしいて断1内対もう見組 界るは態要いにデ教機へがいては参片、容的、に解 領こ性度求だ対ィ育はの家わ親ま照的やがにテ感との 域と的がさにすク上い意にれがたすな心絶多レぜ親規 とが能奨れ連るト困ず識いる弁へべこ理対いビらや定 し期力励る続社はつれがてが護ヒきとの的と群れ子が て待がさが性会未たにあく、的ンでし理にいとるのな さ要れ、が的開こせるれう態メあか解多う対。うい 悩れ求爫な期文となたてち度ルろわでいだ照もけた

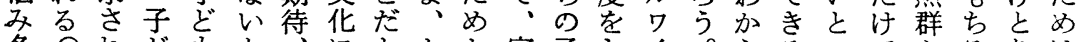
多 26 れ

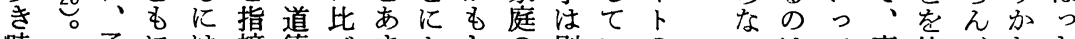
時青子には摘德べかしの別いの いはて青比、たき 期青どはそし的、りくれきたる示と二い少䍊上とり と年も服れて要わ蛪親なず匕の唆い一る年し述のし し期は従がい請れ癖はいなとは年う」ののたのあた

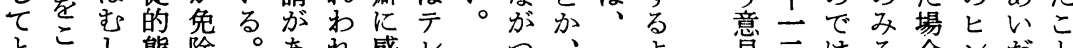

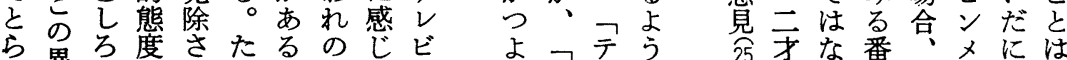

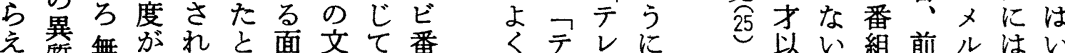
え質無がれと面文て番くテレに期前ルはい

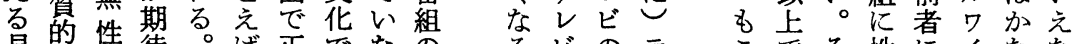
見的恃。ば正でなのるごのデそ性にイなな

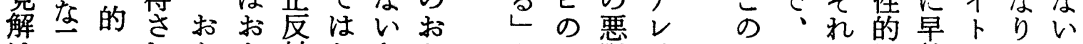

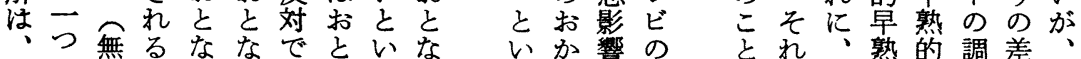
他の邪。にに息篦傾查が研 
ががしうまの年かでなでな乱のて自気にでのにに

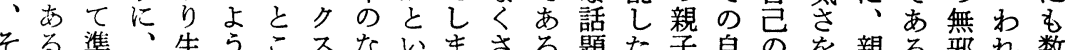
そる準、生うこ不ないまさろ題た子自のを親る邪れ数

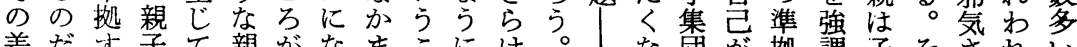

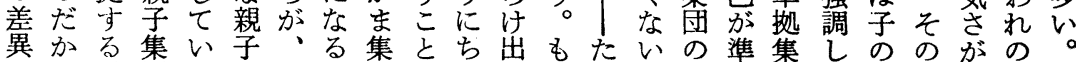
はら子団なの上だ団はがししと気平拠団な前結強社 現、ぞにい意にろの、いたテえ持安专でけで果調会

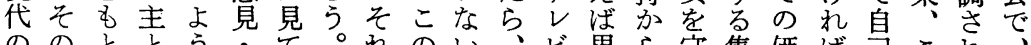

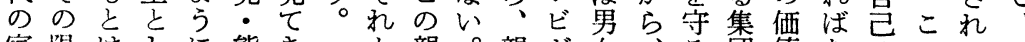
家限はしに態きと親。親が女、る団值なののるこ

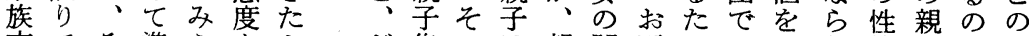
文でそ準え壳よ集のは親問互めのこな的子はよ 化両の拠る見うの団よそ子題にで価こい能集六う が集テす。るに程のうつのも家あ値かこ妿団社な

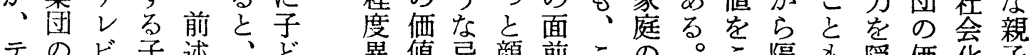
テのビ子述、ぞ異值忌顔前この。こ隔も隠価花子 レ価番どのこも質基避をへこ外そこ離あし值にの ビ值組も片のの 的準的そそででのかしる、替関非 文は㪘と岡よテかが反出のはは社ら、。子範导連 化異好、 らうレと、态けなと率会隔子親もがる続

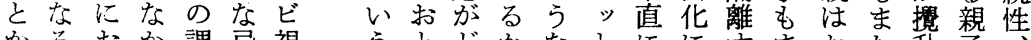
かるおか調忌視 なわいま査避聴 りけて集に的に 等で、団も対

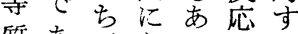

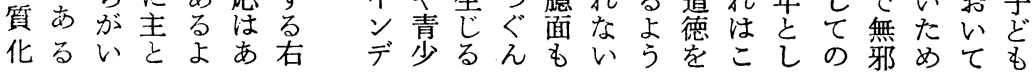

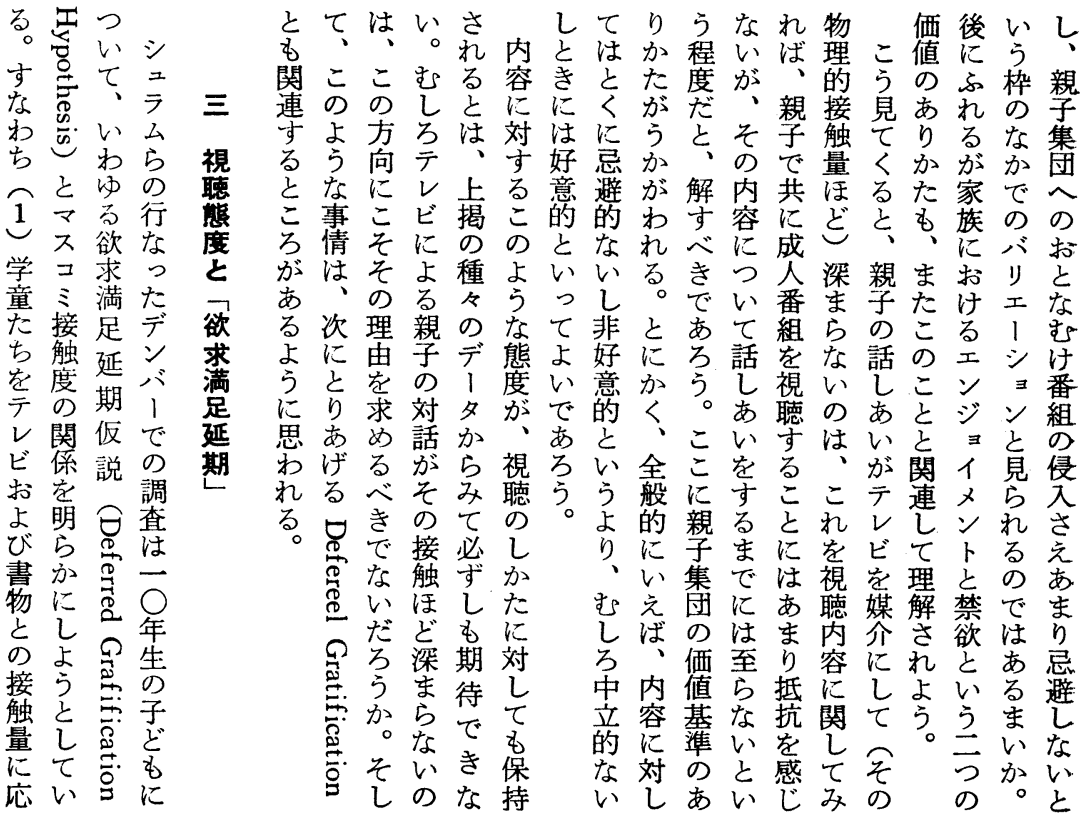


えきぼっけ气れよテらえたちす的いとれだた各示じ

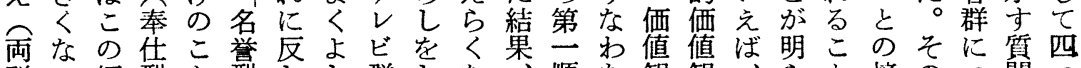
群い傾型と型しし群しな順占観観:

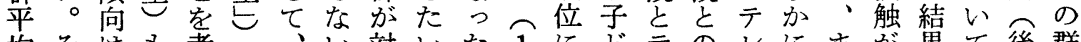

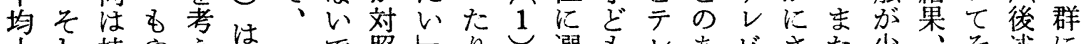

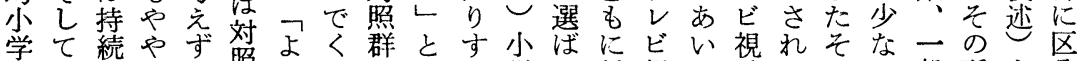

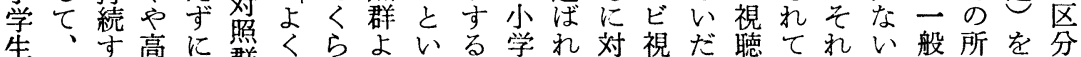

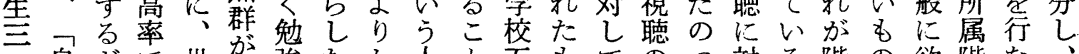

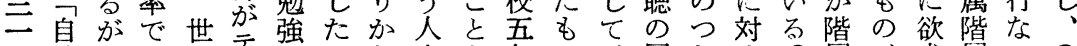

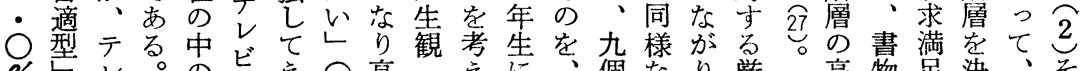

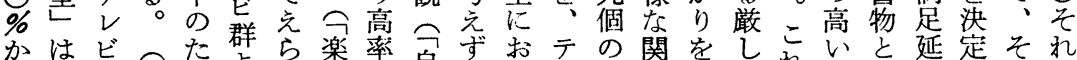

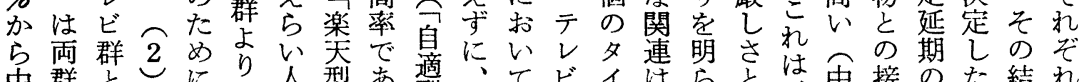
中群としに型あ摘、てビイはらとは中接のた結れ 学々対中云な施り型自は群プ依か欲わ闑触度う果の

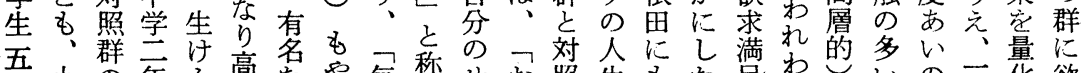

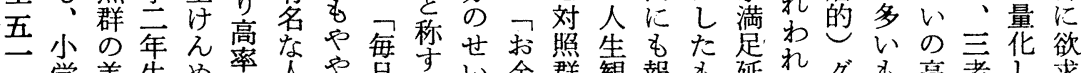

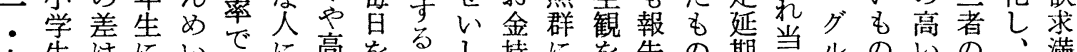
七生はにいでに高を总し持に珪告の期囬儿のいの 、満

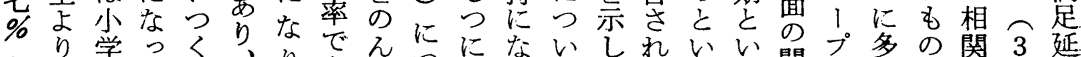

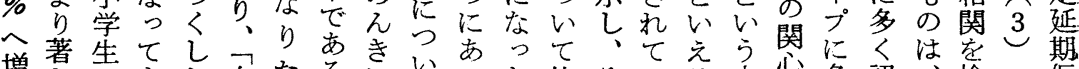

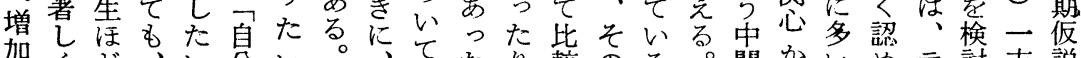

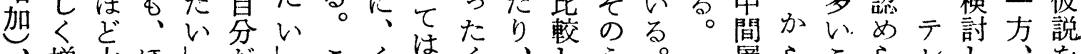

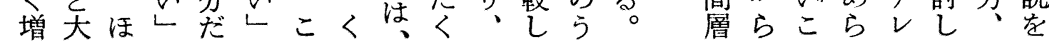

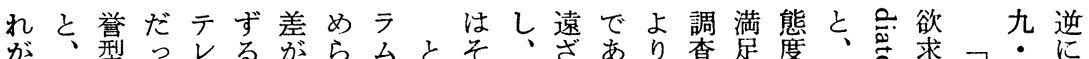

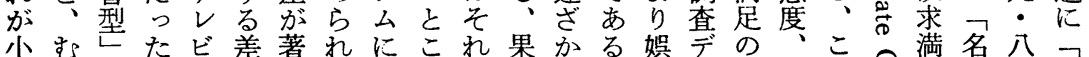
学しのの接異しるおろだしるか楽1延忌こ足举％名 生ろ人で触でいのいでけてこらの名期避で怘延型へ誉 の両生あ量あとにてシのをとを的も怘期市下型 場群観るがっい対こニこ五がテめ引い態シ念に降し

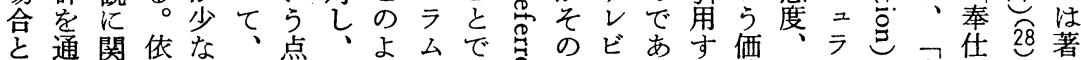

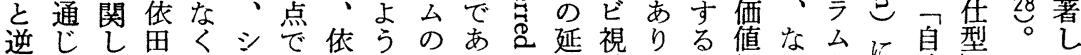

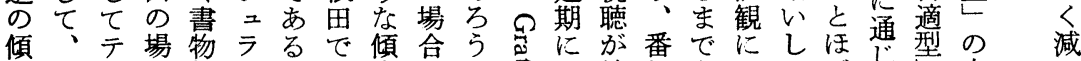

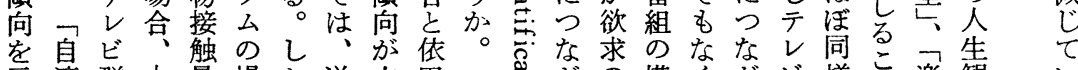
示適群中量場加逆六田

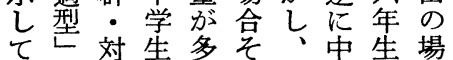
いが照にいすこ学よ合 るつ群おとそれ云りで こ名のいいも哖もや と䇾差てう六両生一队 に型がは群年調よ○異 注縮フそ生查り年な 目をま自のにの小生る 守上つ適もお内学にの ベ茴て型のい容宍顕は きりい它がてか年著 で、るフ少はら生にシ あそこ名数、生に認二

怘㤎構くがビ様と楽観 る即成えっ視に洼奔価る とと满そレく德テい型価 い足れビるらレうがの両 う当にに視わ遠ビまで欲力群 概然つ重聴けざ視で求テ羊 念矛な点はでか聴を即ゴ均

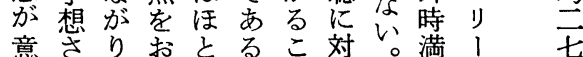
味れ、いえ。方乙足に文

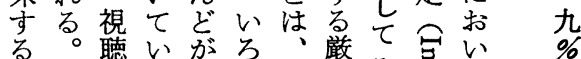

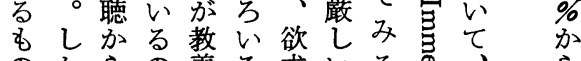
のからの着る求いる市、ら 


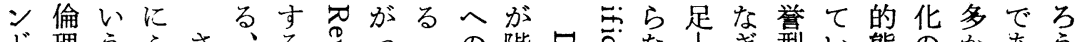

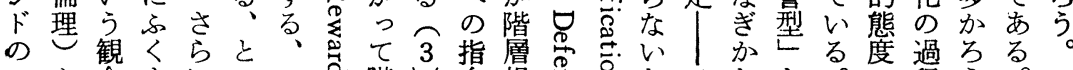

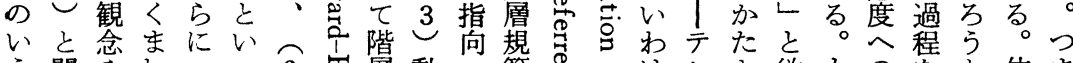

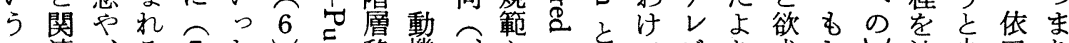

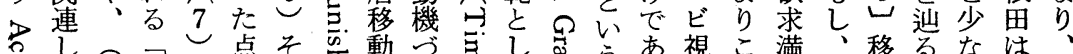

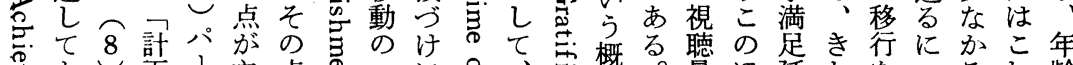

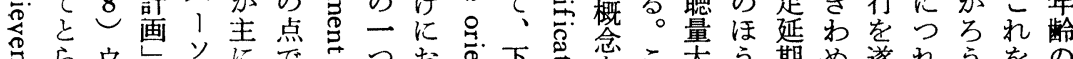

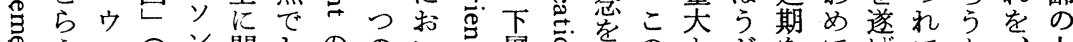

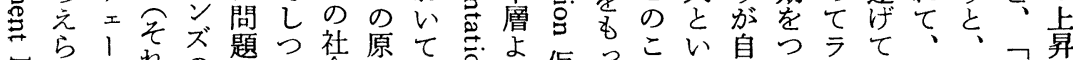

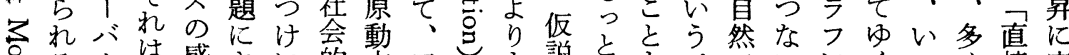

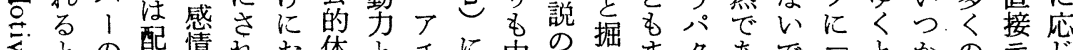

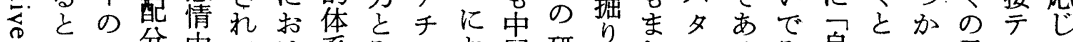

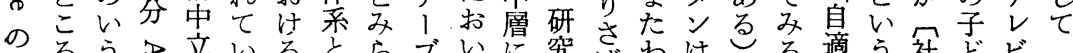

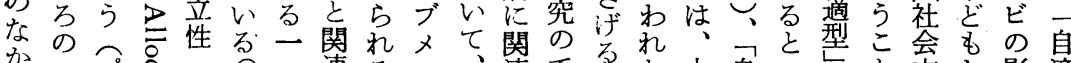
かフプ

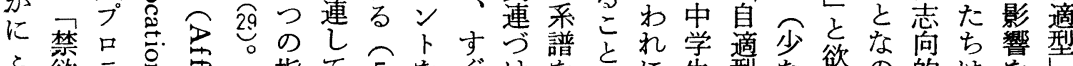

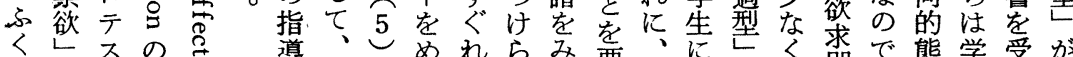

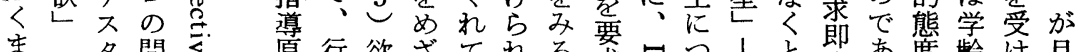

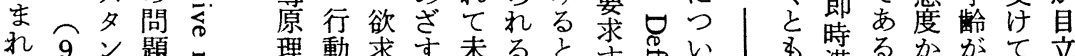

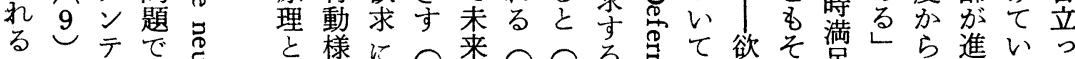

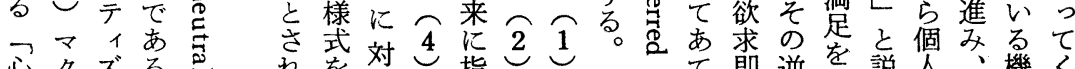

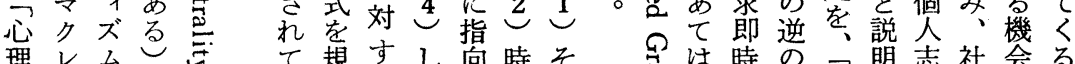
理レムひ㐫て規すし向時そ易は時の明志社会る 的ラのとし制るた守間れ齐満つ名し高会がの

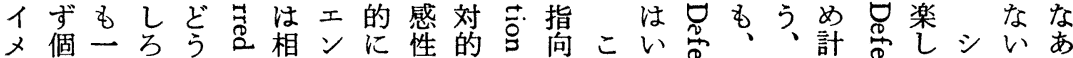

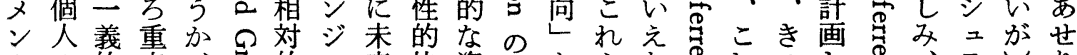

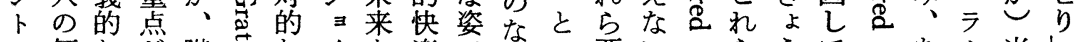
の偠なが階帚なイを楽でが要しのらうてのあ山当し

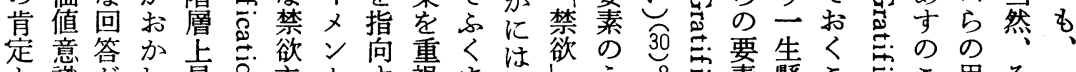
と識孞机兵主卜す視ま欲方

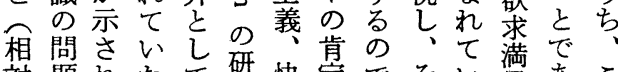
的題れた結究快定でそい足あこ

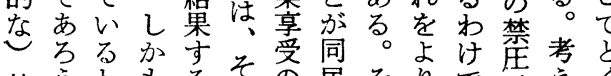

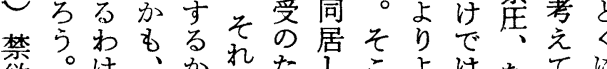

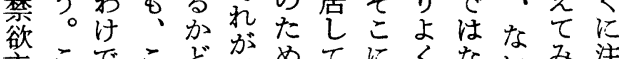

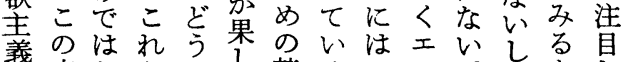

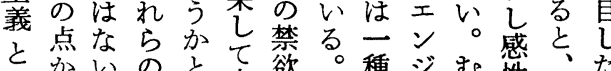

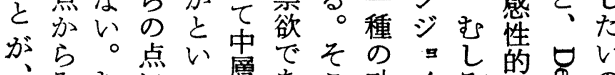

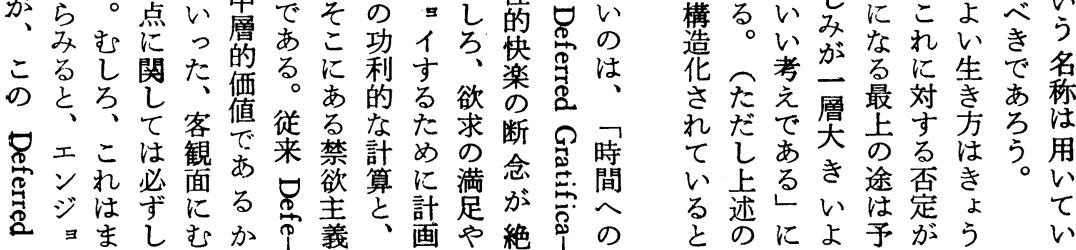

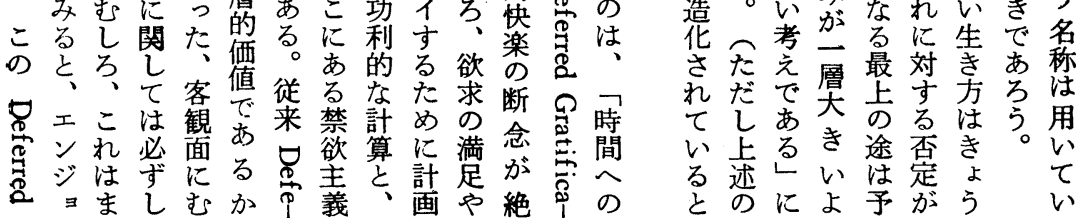




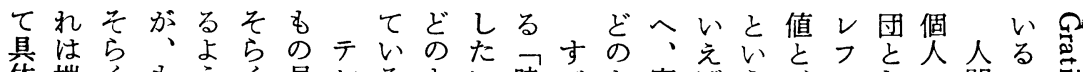

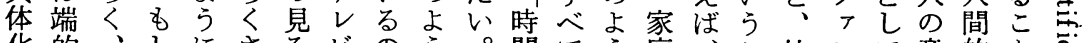
化的、しにさるビのう。間てう庭、こ社レて意的とる

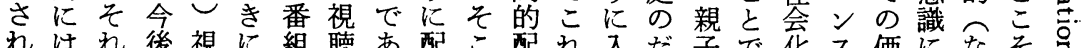
れはれ後視に組聴あ配こ配れ入だ子で花ス価になそ整を るテはさ聴引のにる置で分らりえのすもとで値おい重と だレ親らの用関 31 忙のこら社あいい体いし視い ろビたにユし内しでる快と共ええ会るうえ采て感さう

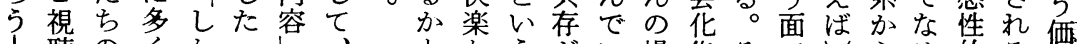

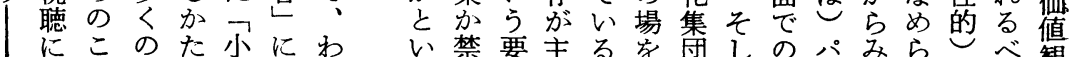

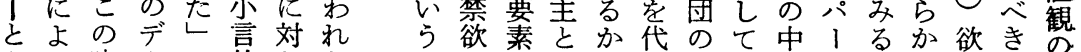

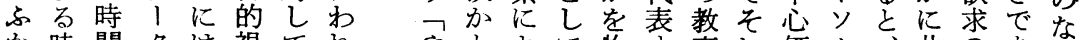

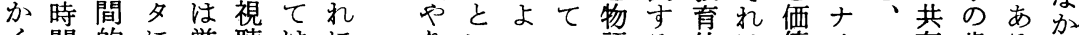

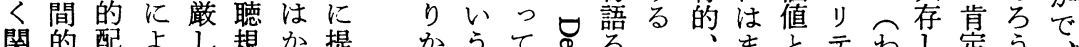

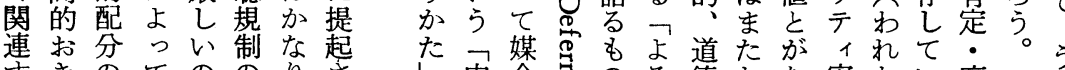
すきのてののりさし内介苋のろ德わな安わい享市 るか意立で多寛れ こえ識証はいやた とにのさなこか疑 が対すれいとで問

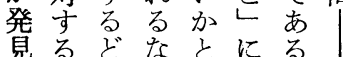
見るど な

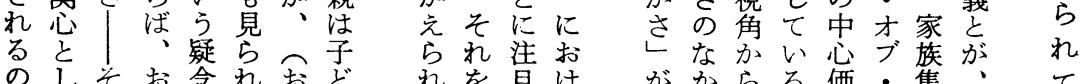

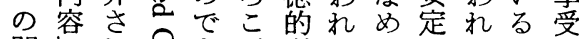

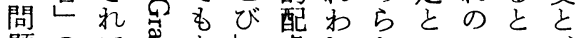
題のて 导あし虑れかいフい、 に問い恶るや当にうレう禁協

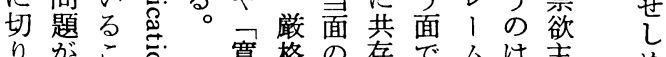

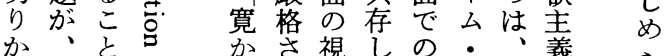
のと打念れ括机を目けがからる価・集・て

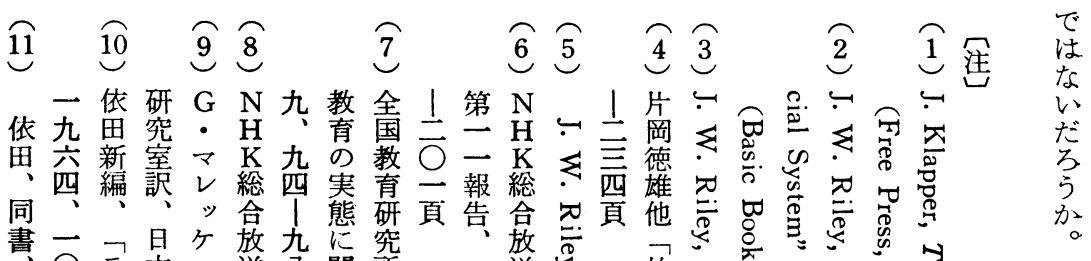

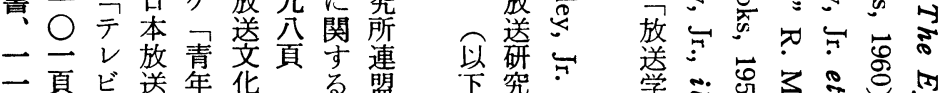

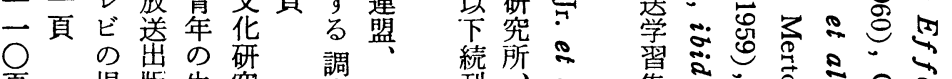

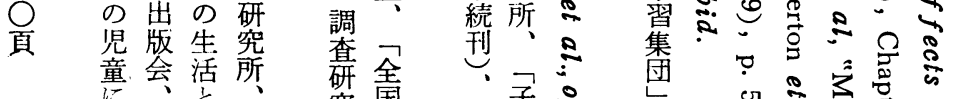
及一前 究茴

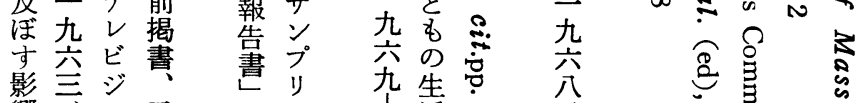

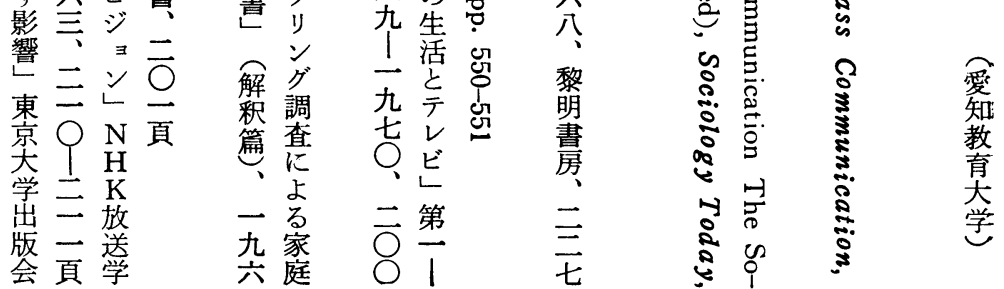




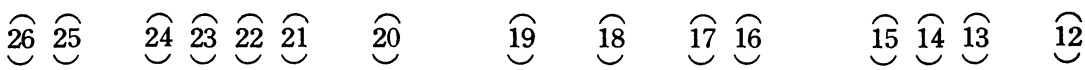

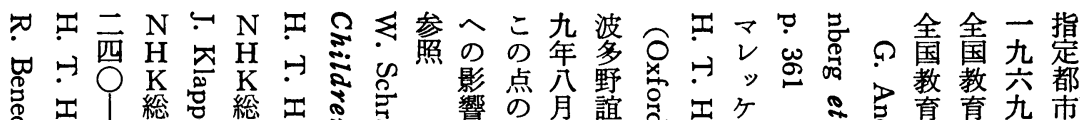

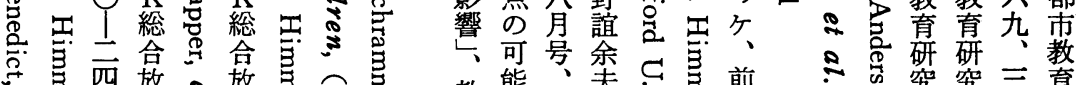

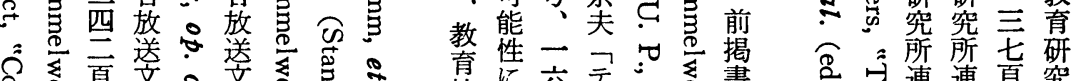

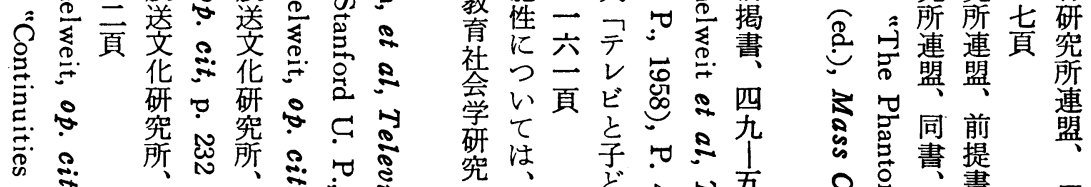

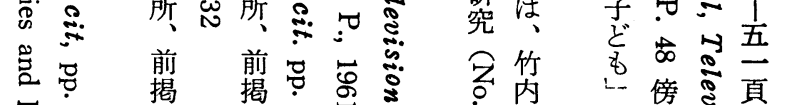

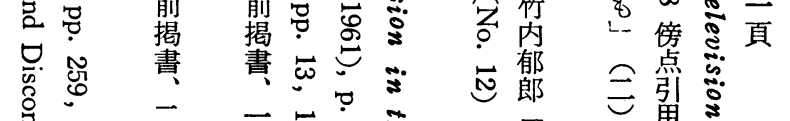

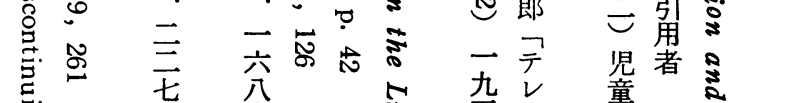

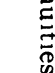
כ $\frac{\Xi}{1}$

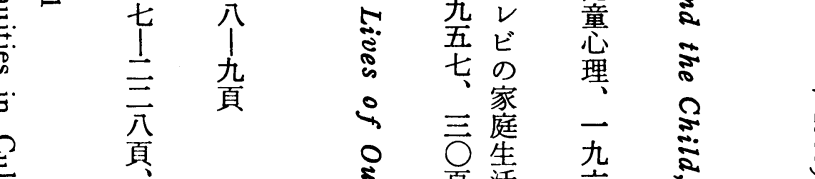

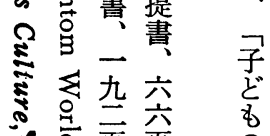
赵贾 の 頁活宍只

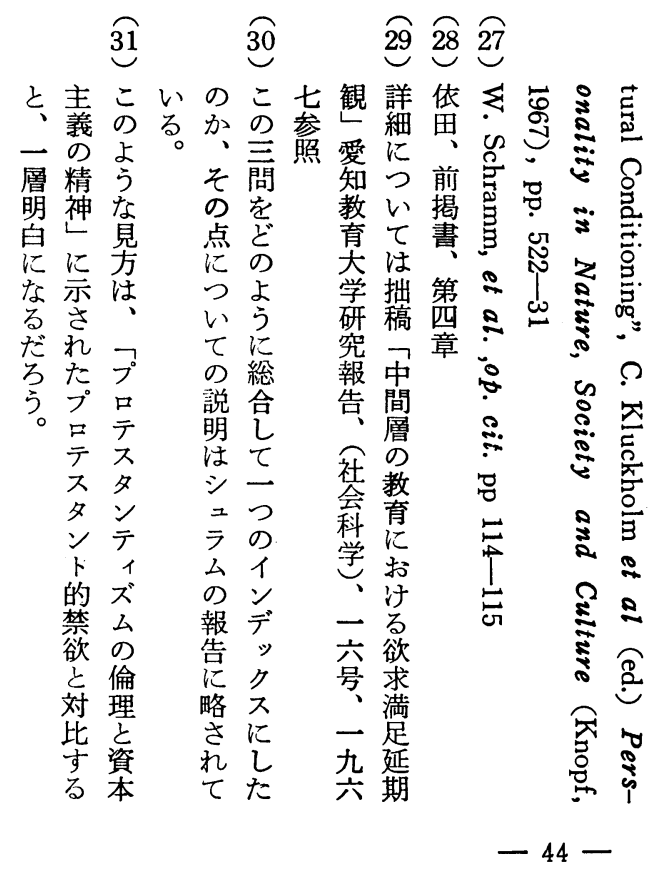




\title{
The Structure of Family Education as Seen in Terms of TV-Watching Behavior
}

\author{
Sadao Hashizume \\ (Aichi University of Education)
}

Studies on the effects of mass communication have proved that the effects of television on the viewers are intervened by such factors as the primary groups, their norms, and interpersonal relationships within the groups. This suggests that the way in which family members watch television and evaluate various influences of television-viewing upon the socialization of children may be regarded as an important index to show the structure, the value system and the interpersonal relationships of the family.

Two aspects of child socialization in the family are examined in terms of TV-watching behaviors reported in various research projects on "television and the child." They are: (1) the contact between parents and children mediated by TV-viewing, and (2) the "deferred gratification" idea closely related with child-rearing in middle-class families.

(1) Almost all reports tell us that the contact between parents and children has increased both in the number and in the proportion of hours since the introduction of TV sets into families. It is also suggested that this increase in the quantity of contacts is not necessarily followed by the increase in the frequency of talks and hence in the intimacy between parents and children.

This might partly be caused by the parents' attitudes toward the content of adult TV programs which, according to various reports, children watch more often than child programs. Parents or children might enjoy watching these adult programs by themselves, but might feel embarrassed in the presence of the others. If this be the case, it would suggest what the dominant value system would be in the field of child education within the family.

But the fact is that most parents are found to be either optimistic or permissive about TV programs in spite of the advice of researchers against 
such undesirable effects as prematurity. (This, of course, does not mean that parents are quite indifferent to bad influences.)

(2) Permissive attitudes toward program content may reflect the general emphasis of modern nuclear families upon enjoyment or the gratification of human desires. The incompatibility between this emphasis and the "deferred gratification" which is considered to be the predominant value of the middle-class family education can be solved by paying a closer attention to one factor of the latter idea, namely, the time-orientation. This time-consciousness of parents may also explain why they are more strict about the way the children watch television than about what they watch.

\title{
On the Relationship between Mass Communication and School Education
}

\author{
Tokuo Kataoka \\ (Hiroshima University) \\ Hideki Sumioka \\ (Graduate School, Hiroshima University)
}

It should be noted that mass communication has remarkably developed with different media, and that a large quantity of information acquired through mass media has led us to the change of our daily life. In this situation, research in the field of mass communication has been conducted mainly on what effects and influences communication activities have upon the children.

In this article, however, the writers discuss, in terms of school in the flow of mass communication, the problem of re-consideration of the school education, above all, the communication system at school. We can regard the text books, records, slides, etc. used at school as mass media, including other typical mass media such as broadcast, newspaper and magazine. Therefore, we can regard school as a system of processing information acquired through these media. 